\title{
PERBANDINGAN PENGARUH KOMBINASI LATIHAN HOLD RELAX DAN OPEN KINETIC CHAIN DENGAN LATIHAN HOLD RELAX DAN CLOSE KINETIC CHAIN TERHADAP PENINGKATAN KEMAMPUAN FUNGSIONAL PASIEN OSTEOARTRITIS KNEE
}

\author{
Khairuruizal , Irianto, Yonathan Ramba \\ Program Studi Fisioterapi Fakultas Keperawatan Universitas Hasanuddin, Makassar - Indonesia
}

Corresponding author:

\section{Khairuruizal}

Program Studi Fisioterapi Fakultas Keperawatan Universitas Hasanuddin, Makassar - Indonesia Email: reezhal28@gmail.com

\section{Article Info:}

Received: 20 May 2019

Revised: 21 June 2019

Accepted: 18 Oct 2019

Available online: 21 Oct 2019

Keywords: Hold Relax, Open

Kinetic Chain, Close Kinetic

Chain, , Osteoarthritis knee,

WOMAC

DOI: $10.20956 / n m s j . v 4 i 2.6564$

\begin{abstract}
Introduction: Knee osteoarthritis is a disease caused by degeneration factors that are most often found in musculoskeletal diseases. This study aims to compare the effect of a combination of exercise hold relax and open kinetic chain with hold relax and close kinetic chain to increase functional ability in patients with osteoarthritis knee.

Methods: This study used a quasi-experimental method with one group pretestposttest design. The sampling technique was purposive sampling with a total sample of 26 people who met the inclusion criteria.

Result: Paired sample $\mathrm{T}$ test in the hold relax and open kinetic chain group obtained $\mathrm{p}=0,000(\mathrm{p}<0.05)$. Whereas in the treatment group 2 hold relax and close kinetic chain $p$ value $=0,000(p<0.05)$ which means that there is an influence on functional abilities before and after treatment. From the results of testing with Independent t-test, the value of $p=0,000(p<0.05)$ means that there is a difference in the effect of hold relax and open kinetic chain with hold relax and close kinetic chain to increase the functional ability of patients with osteoarthritis knee.

Conclusion: There is a different effect between the Combination of Hold Relax and Open Kinetic Chain exercises with the combination of Hold Relax and Close Kinetic Chain exercises on improving the functional ability of knee osteoarthritis patients.
\end{abstract}

\section{PENDAHULUAN}

Secara global osteoarthritis (OA) knee dan hip, merupakan salah satu faktor predisposisi yang menyebabkan kecacatan dan penurunan level fungsional seseorang. Berdasarkan penelitian yang dilakukan Cross (2014), OA knee dan hip menempati peringkat 11 sebagai penyumbang kecacatan. Menurut penelitian di Belanda Institute for Public Health, prevalensi OA lutut pada mereka yang berusia 75 tahun adalah $50 \%$, dan pada usia 45 tahun keatas sebesar 19,2\%. ${ }^{1}$
Osteoartritis merupakan salah satu penyakit yang disebabkan oleh faktor degenerasi yang paling sering dijumpai pada penyakit musculoskeletal. Osteoartritis merupakan penyebab terbanyak munculnya keterbatasan gerak dan fungsi sendi, serta lokasi yang sering terkena adalah sendi lutut. $^{2}$

Prevalensi penderita osteoartritis di dunia tahun 2004 mencapai 151,4 juta jiwa dan 27,4 juta jiwa berada di Asia Tenggara. ${ }^{3}$ Sedangkan di Indonesia pravalensi osteoartritis berjumlah $8,1 \%$ dari total 
populasi. Pasien osteoartritis lutut menderita kombinasi nyeri sendi, kekakuan, ketidakstabilan, pembengkakan, dan kelemahan otot. Hal ini menyebabkan penurunan kualitas hidup, aktivitas hidup sehari-hari (ADL). Delapan puluh persen pasien dengan OA lutut menderita penurunan mobilitas sementara 20\% dari mereka menderita ketidakmampuan untuk melakukan kegiatan sehari-hari. ${ }^{4,5}$

Gangguan fungsional pada penderita osteoartritis disebabkan karena adanya rasa nyeri. Nyeri ini berhubungan dengan penurunan kekuatan otot. Otot tersebut merupakan stabilisator utama sendi lutut yang berfungsi sebagai pelindung struktur sendi lutut. Dengan adanya nyeri ini juga akan menurunkan luas gerak sendi karena dengan adanya nyeri ini sendi menjadi jarang digerakkan. ${ }^{6}$

Menurunnya kekuatan disertai dengan hilangnya daya kontraksi fungsional otot akan menghasilkan kontraksi yang tidak sinergis (non-fisiologis) sehingga meningkatkan stress pembebanan yang berlebihan pada salah satu permukaan kontak sendi, yang kemudian akan meningkatkan progresifitas proses degeneratif sendi. ${ }^{7}$

Gangguan keseimbangan posture juga merupakan permasalahan yang terjadi pada penderita osteoartritis knee. Kerusakan pada rawan sendi menyebabkan ligament kendur dan kapsul sendi mengalami kerusakan, sehingga reseptor proprioseptif yang terdapat pada sendi, tulang, otot dan ligament mengalami gangguan. Proprioseptif berfungsi sebagai salah satu komponen pengontrol keseimbangan. Penurunan keseimbangan tidak hanya dipengarui proprioseptif namun faktor kelemahan otot juga mengakibatkan penurunan keseimbangan postural dan stabilitas sendi. Adanya kelemahnya otot dan penurunan keseimbangan posture meningkatkan resiko jatuh pada penderita osteoartritis knee. Sehingga dengan resiko jatuh tinggi dan nyeri gerak mengakibatkan gangguan aktivitas fungsional seperti duduk-berdiri, naik turun tangga bahkan hilangnya kemandirian. ${ }^{8}$

Program latihan optimal untuk osteoartritis knee harus bertujuan mengurangi rasa sakit dan meningkatkan rentang gerakan lutut, serta meningkatkan fungsi umum. Program ini juga harus fokus pada peningkatan kapasitas aerobik, kekuatan otot quadriceps, atau kinerja ekstremitas bawah. Latihan tungkai bawah ini umumnya diklasifikasikan sebagai latihan open kinetic chain dan close kinetic chain. ${ }^{9}$ Open kinetic chain $(O K C)$ adalah suatu latihan gerak aktif yang melibatkan satu otot dan sendi saja (single joint) dan tanpa disertai pergerakan pada segmen proksimalnya dan closed kinetic chain (CKC) adalah suatu latihan gerak aktif yang melibatkan beberapa kelompok otot sekaligus dan beberapa sendi (multiple joint). ${ }^{2}$

Exercise (latihan) juga merupakan metode pengurangan nyeri dan peningkatan LGS. Jenis exercise yang dapat diberikan salah satunya adalah menggunakan hold relax. Hold relax merupakan suatu kontraksi isometrik optimal pada kelompok otot antagonis yang diikuti rileksasi, bertujuan mengurangi nyeri dan meningkatkan jangkauan gerak pasif. ${ }^{10}$

Berdasarkan penelitian Verma, (2012), Gbiri CA., Okafor UAC \& Alade MT., (2013), Olagbegi OM., Adegoke BOA, \& Odole A., (2016) latihan open kinetic chain dan closed kinetic chain bermanfaat untuk peningkatan kekuatan otot dan kemampuan fungsional pada pasien osteoartritis knee. ${ }^{11,12,13}$ Sedangkan, menurut penelitian Maini (2013), hold relax dapat menurunkan spasme, meningkatkan lingkup gerak sendi dari sendi yang mengalami keterbatasan dan mampu mengurangi nyeri. Dan hasil penelitian oleh Nurdin, M., Gani, M. dan Ramba, Y., (2013) juga menunjukkan bahwa hold relax signifikan dalam menurunkan nyeri pada osteoartritis knee. ${ }^{14,15}$

Berdasarkan uraian dalam latar belakang diatas mengenai masalah gangguan kemampuan fungsional pasien osteoartritis knee, sehingga menjadi landasan bagi penulis untuk melakukan penelitian mengenai perbandingan pengaruh latihan open kinetic chain dan close kinetic chain yang dikombinasikan dengan latihan hold relax dalam meningkatkan kemampuan fungsional pasien osteoartritis knee.

\section{METODE}

\section{Lokasi dan rancangan penelitian}

Penelitian ini dilakukan di RS Dr. Tadjuddin Chalid dan Klinik Physio Prima Makassar. Penelitian ini menggunakan metode quasi eksperimental menggunakan one grup pre and post test design.

\section{Populasi dan sampel}

Populasi dalam penelitian ini adalah semua penderita osteoartritis knee yang datang berobat 
ke Rumah Sakit Dr. Tadjuddin Chalid Makassar dan Klinik Physio Prima Makassar yaitu berjumlah 36 orang. Berdasarkan populasi maka didapatkan jumlah sampel sebesar 26 orang yang sesuai dengan kriteria inklusi yang telah dibuat oleh peneliti.

\section{Metode pengumpulan data}

Pengumpulan data dilakukan oleh peneliti dengan penyebaran informed consent kepada pasien untuk memperoleh informasi meliputi; nama, umur, dan jenis kelamin. Untuk penilaian kemampuan fungsionalnya peneliti melakukan pengisian form kuesioner WOMAC dengan langsung bertanya kepada pasien baik saat pre test maupun post test. Sampel penelitian dibagi menjadi dua kelompok yaitu kelompok I diberikan kombinasi latihan hold relax dan open kinetic chain 3 kali seminggu, selanjutnya kelompok II diberikan kombinasi latihan hold relax dan close kinetic chain 3 kali seminggu, sehingga pada dua kelompok tersebut dilakukan intervensi masing-masing sebanyak 9 kali perlakuan selama 3 minggu.

\section{Analisis Data}

Data yang diperoleh dari penelitian ini adalah data primer dari hasil pengukuran kemampuan fungsional pada pasien ostarthritis knee sebelum dan sesudah pemberian latihan menggunakan Western Ontario and McMaster Universities Osteoarhtritis Index (WOMAC). Data yang diperoleh diolah dengan program komputer SPSS versi 24 yaitu dilakukan uji normalitas dengan uji shapiro-wilk untuk mengetahui sebaran data. Setelah diketahui sebaran data berdistribusi normal, maka selanjutnya dilakukan uji paired sample t-test untuk mengetahui pengaruh kombinasi latihan hold relax dan open kinetic chain terhadap peningkatan kemampuan fungsional pasien osteoartritis knee serta pengaruh kombinasi latihan hold relax dan close kinetic chain terhadap peningkatan kemampuan fungsional pasien osteoartritis knee. Selanjutnya, untuk mengetahui beda pengaruh antara kelompok 1 dan kelompok 2 dilakukan uji Independent sample t-test.

\section{HASIL}

RS Dr. Tadjuddin Chalid dan Klinik Physio Prima Makassar mulai dari tanggal 26 Maret sampai 26 April 2019. Terdapat 26 sampel yang termasuk kriteria inklusi. Adapun hasil penelitian dirangkum dalam Tabel 1.

\section{Analisis Univariat}

Berdasarkan Tabel 1 menunjukkan karakteristik sampel penelitian yaitu; jenis kelamin dan usia. Jumlah sampel penelitian yang berjenis kelamin laki-laki adalah 11 orang $(42,3 \%)$ dan jumlah sampel penelitian yang berjenis kelamin perempuan adalah 15 orang $(57,7 \%)$. Usia sampel penelitian diklasifikasikan dalam rentang usia 4050 tahun sebanyak 6 orang $(23,1 \%)$, usia 51-60 tahun 8 orang $(30,8 \%)$ dan usia $>60$ tahun 12 orang $(46,2 \%)$.

Pada tabel 2 untuk distribusi hasil pre-test skor WOMAC pada kelompok I kategori sedang (2548) sebanyak 1 orang $(7,7 \%)$ dan kategori berat (49-72) sebanyak 12 orang $(92,3 \%)$. Untuk posttest kategori sedang (25-48) 7 orang $(53,8 \%)$ dan kategori berat (49-72) 6 orang (46,2\%). Untuk distribusi hasil pre-test skor WOMAC pada kelompok II kategori sedang (25-48) sebanyak 1 orang $(7,7 \%)$ dan kategori berat (49-72) sebanyak 12 orang $(92,3 \%)$. Untuk post-test kelompok II kategori ringan (0-24) 3 orang $(23,1 \%)$, kategori sedang (25-48) 9 orang $(69,2 \%)$ dan kategori berat (49-72) 1 orang $(7,7 \%)$.

\section{Analisis Bivariat \\ Uji normalitas}

Uji normalitas (tabel 3) dengan menggunakan uji Saphiro-wilk pada kedua kelompok perlakuan dimana uji normalitas pada kelompok I didapatkan hasil pre-test $p=0.517$, post-test $p=$ 0,450 , sedangkan pada kelompok II diperoleh hasil pre-test $p=0,296$, post-test $p=0,173$ yang berarti $\mathrm{p}>0,05$ sehingga data berdistribusi normal. Selanjutnya uji normalitas pada hasil selisih prepost kelompok I diperoleh hasil $p=0,788$ dan hasil selisih pre-post kelompok II diperoleh hasil $p=$ 0,128 yang berarti $p>0,05$ maka data tersebut berdistribusi normal.

\section{Uji paired sample T test}

Hasil pengujian hipotesis menggunakan uji paired sample $t$ test dimana pretest dan post test pada kelompok I diperoleh hasil $p=0,000(p<0,05)$ berarti terdapat perbedaan yang signifikan antara sebelum dan sesudah perlakuan. selanjutnya pretest dan post test pada kelompok II hasilnya $\mathrm{p}=0,000(p<0,05)$ berarti terdapat perbedaan yang signifikan antara sebelum dan sesudah perlakuan.

Hal ini menunjukkan bahwa hipotesis 1 dan hipotesis 2 penelitian diterima, yaitu bahwa terdapat pengaruh pemberian kombinasi latihan hold relax dan open kinetic chain terhadap 
peningkatan kemampuan fungsional pasien osteoartritis knee (tabel 4). Dan pada hipotesis 2 terdapat pengaruh pemberian kombinasi latihan hold relax dan close kinetic chain terhadap peningkatan kemampuan fungsional pasien osteoartritis knee.

\section{Uji independent sample T test}

Pada Tabel 5, hipotesis uji beda pengaruh 2 kelompok independen dilakukan uji Independent sample t-test karena data berdistribusi normal. Setelah dilakukan uji Independent sample t-test pada hasil selisih pre-post kelompok I dan hasil selisih pre-post kelompok II diperoleh hasil $p=$ 0,000 yaitu $p<0,05$, yang berarti hipotesis 3 diterima yaitu terdapat perbedaan pengaruh kombinasi latihan hold relax dan open kinetic chain dengan hold relax dan close kinetic chain terhadap peningkatan kemampuan fungsional pasien osteoartritis knee.

\section{PEMBAHASAN}

Karakteristik Sampel Penelitian

Hasil analisis deskriptif tabel 1 menunjukkan bahwa rentang umur sampel $>60$ tahun merupakan rentang umur dengan jumlah penderita osteoartritis terbanyak. Hal ini sesuai dengan hasil penelitian Paerunan (2019) yang menyimpulkan bahwa terdapat peningkatan kejadian osteoartritis lutut seiring dengan pertambahan usia dimana angka kejadian OA knee paling tinggi terjadi pada usia 60-75 tahun. Bertambahnya usia merupakan faktor kontributor utama penyebab kejadian osteoarthritis knee terutama pada usia 50 tahun keatas. ${ }^{16,17}$ Penelitian yang lain menunjukkan bahwa osteoartritis knee sebagian terjadi pada usia diatas 50 tahun yaitu sebanyak 22 orang $(91,7 \%) .{ }^{18}$

Karakteristik sampel berdasarkan jenis kelamin menunjukkan bahwa jenis kelamin perempuan lebih banyak dibandingkan dengan laki-laki yaitu 15 orang $(57,7 \%)$ perempuan dan 11 orang $(42,3 \%)$ laki-laki. Dimana ada penelitian lain, yaitu penelitian Miftakuljannah dan Hartutik (2018), menyebutkan bahwa jenis kelamin perempuan lebih besar yakni sebanyak 57 orang $(90,67 \%)$ dibandingkan laki-laki sebanyak 6 orang $(9,5 \%)^{19}$ Perempuan memiliki resiko dua kali lipat terkena cedera dan osteoartritis knee karena perbedaan bentuk panggul perempuan yang lebih lebar, yang dapat mengakibatkan kaki lebih merapat (valgus) kebagian lutut sehingga tekanan pada permukan sendi lutut menjadi tidak merata. Selain itu massa otot disekitar sendi lutut perempuan lebih sedikit dibandingkan laki-laki. ${ }^{20}$

Pada tabel 2 dari hasil pre-test skor WOMAC pada kelompok I kategori sedang (25-48) sebanyak 1 orang $(7,7 \%)$ dan kategori berat (4972 ) sebanyak 12 orang (92,3\%). Untuk post-test kategori sedang (25-48) 7 orang $(53,8 \%)$ dan kategori berat (49-72) 6 orang $(46,2 \%)$, disini terdapat penurunan pada 6 orang dari kategori berat ke kategori sedang. Untuk distribusi hasil pre-test skor WOMAC pada kelompok II kategori sedang (25-48) sebanyak 1 orang $(7,7 \%)$ dan kategori berat (49-72) sebanyak 12 orang ( 92,3\%). Untuk post-test kelompok II kategori ringan (0-24) 3 orang $(23,1 \%)$, kategori sedang (25-48) 9 orang $(69,2 \%)$ dan kategori berat (49$72) 1$ orang $(7,7 \%)$, disini juga terdapat penurunan pada 10 orang dari kategori berat ke kategori sedang dan 2 orang dari kategori berat ke kategori ringan. Dan terjadi penurunan pada 1 orang dari kategori sedang ke kategori ringan. Hal ini sesuai dengan penelitian Verma (2012), "Comparing open kinetic chain with closed kinetic chain exercise on quadriceps strength and functional status of women with osteoarthritic knees" bahwa terjadi penurunan skor WOMAC antara sebelum dan sesudah pemberian intervensi. Verma menjelaskan bahwa latihan penguatan otot quadriceps berpengaruh pada penurunan nyeri lutut, dan ada bukti berkualitas tinggi bahwa latihan dapat mengurangi nyeri dan meningkatkan kemampuan fisik seperti latihan-latihan peningkatan kekuatan otot, gaya berjalan, latihan ROM dan latihan stabilitas yang bervariasi. ${ }^{20}$

\section{Pengaruh Pemberian Kombinasi Latihan Hold Relax dan Open Kinetic Chain}

Pada penelitian ini hasil perlakuan hold relax dan open kinetic chain dalam pengujian parametrik menggunakan paired sample t-test didapatkan nilai $\mathrm{p}=0,000(\mathrm{p}<0,05)$ yang artinya Ha diterima dan Ho ditolak, yang berarti ada pengaruh terhadap peningkatan kemampuan fungsional sebelum dan sesudah pemberian latihan. Hal ini sesuai dengan penelitian "Perbedaan Pengaruh Penambahan Sling Exercise Pada Latihan Closed Kinetic Chain Dan Open Kinetic Chain Terhadap Peningkatan Kemampuan Fungsional pada Osteoarthritis" menyimpulkan bahwa kelompok perlakuan sling exercise dan open kinetic chain memiliki hasil yang signifikan yaitu $p=0,034$ $(p<0,05)$ dimana terjadi peningkatan kekuatan otot secara signifikan, dimana dengan 
peningkatan kekuatan otot dapat meningkatan kemampuan fungsional sendi lutut. ${ }^{21}$

Pada latihan open kinetic chain peningkatan kekuatan otot terfokus pada satu otot saja, sehingga menghambat terjadinya atropi otot, meningkatkan sirkulasi darah, dan terjadi peningkatan kekuatan otot yang dapat meningkatkan kemampuan fungsional. ${ }^{22}$ Pengaruh latihan open kinetic chain pada jaringan yaitu mengubah lingkungan lokal pada serabut matriks yang tidak beraturan melalui gerak antar persendian secara berlahan yang akan menstimulasi mechano growth factor karena terjadinya peningkatan lubrication sebagai syarat meningkatnya jumlah zat plastin. Zat plastin ini berfungsi sebagai pengganti jaringan baru yang terdiri atas kandungan asam amino protein yang akan disintesis dengan fasilitasi gerak perlahan yang akan mengurai endapan dan akan terbentuk jarak baru untuk mengatur sintesis kolagen, yang bertujuan menurunkan adhesive abnormal formasi (kekakuan). Melalui peningkatan kontraktil protein dan sistem oksidasi pada muscle belly qudriceps, ditandai dengan meningkatnya pasokan oksigen otot sebagai awal terjadinya peningkatan metabolisme dan perbaikan jaringan dengan peningkatan produksi jaringan yang baru serta perbaikan pada tulang rawan maka akan meningkatkan Range of Motion (ROM) sendi lutut. $^{2}$

\section{Pengaruh Pemberian Kombinasi Latihan Hold Relax dan Close Kinetic Chain}

Pada kelompok perlakuan II yaitu kombinasi latihan hold relax dan close kinetic chain setelah dilakukan penilaian WOMAC, selanjutnya dilakukan uji paired sample t test. Dari hasil uji tersebut didapatkan nilai $p=0,000$ yang berarti $(p<0,05)$ yang berarti $\mathrm{Ha}$ diterima atau ada pengaruh kombinasi latihan hold relax dan close kinetic chain terhadap peningkatan kemampuan fungsional pasien osteoartritis knee. Hal ini sesuai dengan penelitian Gbiri et al., (2012) "Comparative Efficacy of Open-chain and Closechain Kinematics on Proprioception, Muscles' Strength and Functional Performances in Individual with Knee Osteoarthritis" yang menyimpulkan bahwa latihan close kinetic chain efektif meningkatkan kemampuan fungsional dan menurunkan gejala dan tingkat keparahan pada penderita osteoartritis knee. ${ }^{23}$

Latihan closed kinetic chain merupakan suatu metode penerapan latihan penguatan dimana dalam pemberian latihan pasien berada pada posisi menumpu berat badan dan tungkai kontak langsung dengan permukaan lantai. Latihan yang diberikan dapat meningkatkan kekuatan otot quadriceps femoris. ${ }^{24}$ Latihan close kinetic chain menyediakan stimulus proprioseptif dan kinestetik yang besar melalui aproksimasi sendi yang dihasilkan. Kontraksi multiple disertai elemen menumpu berat badan (pembebanan axial) selama proses close kinetic chain menyebabkan aproksimasi pada sendi, hal ini menstimulasi mekanoreseptor pada otot dan reseptor disekitar sendi untuk meningkatkan input sensoris dalam proses kontrol gerakan. ${ }^{25}$

Latihan ini dapat menghasilkan ko-kontraksi (kontraksi agonis-antagonis secara bersamaan), aproksimasi dan aktivasi otot yang multiple yang semuanya berkaitan dan memiliki peranan yang sangat besar dalam terciptanya gerakan yang fungsional. Ko-kontraksi menyebabkan otot mampu menstabilkan sendi secara lebih baik sehingga bepengaruh terhadap kualitas gerakan yang dihasilkan. Aproksimasi akan menstimulasi reseptor pada sendi serta meningkatkan kongruenitas sendi yang juga sangat membantu dalam kestabilan. Kontraksi otot yang multiple akan sangat membantu menghasilkan gerakan yang sinergis sesuai dengan tahapan-tahapan gerakan normal. ${ }^{25}$ Latihan close kinetic chain mampu meningkatkan kemampuan fungsional pada sendi lutut dan memberikan latihan dengan jangkuan yang lebih luas dalam gerak sendi. ${ }^{26}$

\section{Perbandingan Pengaruh Pemberian Kombinasi Latihan Hold Relax dan Open Kinetic Chain dengan Hold Relax dan Close Kinetic Chain}

Dari hasil uji independent t test diperoleh nilai $p=$ 0,000 yang berarti $\mathrm{p}<0,05$ sehingga Ha diterima dan Ho ditolak artinya ada perbedaan nilai index WOMAC antara kelompok perlakuan I dengan kelompok I setelah diberikan intervensi. Sehingga dapat disimpulkan ada perbedaan pengaruh yang signifikan antara latihan kelompok I kombinasi latihan hold relax dan open kinetic chain dengan latihan kelompok II kombinasi latihan hold relax dan close kinetic chain terhadap peningkatan kemampuan fungsional pasien osteoartritis knee.

Hal ini dikarenakan karena pada prinsipnya latihan closed kinetic chain adalah latihan yang menguatkan otot agonis dan antagonis secara bersamaan dan merupakan latihan yang lebih fisiologi untuk anggota gerak bawah, dimana latihan ini melibatkan sendi hip, knee dan ankle. 
Dengan posisi trunk tegak dan pada saat hip fleksi $15^{0}$, pada keadaan ini otot quadriceps berfungsi sebagai penggerak fleksi, dan otot hamstring berfungsi sebagai pengerak ekstensi dan pada saat knee fleksi $30^{\circ}$, maka kerja otot tersebut menjadi berbeda, dimana otot quadriceps sebagai kontrak eksentrik untuk mengontrol fleksi lutut dan group otot hamstring sebagai kontrak konsentris untuk mengontrol ekstensi lutut atau memperpanjang lutut, paha belakang dan ankle fleksi $10^{\circ}$ yang mana disini otot yang bekerja otot soleus berfungsi untuk menstabilkan tibia, otot tibialis anterior sebagai kontraksi eksentrik dan otot gastrocnemius sebagai kontrak kosentrik dari sendi ankle selain itu gastrocnemius berfungsi sebagai daya penggerak, walaupun pada kondisi ini ankle hanya berfungsi sebagai stabilisasi tubuh. Dengan penguatan yang melibatkan lingkup gerak sendi yang dapat terjadi perubahan panjang otot akan dapat menguatkan otot secara bersamaan antara otot agonis dan antagonis. ${ }^{25}$

Selain itu, teknik gerak closed kinetic chain adalah latihan gerak yang sesuai dengan bidang anatomi sendi lutut yaitu gerak fleksi-ekstensi dan gerak yang ditujukan untuk aktivitas sehari-hari (Activity Daily Living) seperti jongkok ke berdiri dan toileting. Dengan fleksibilitas dan kekuatan otot yang baik akan mendukung kemampuan gerak dalam melakukan aktivitas sehari-hari. ${ }^{2}$

\begin{tabular}{|c|c|c|}
\hline Karakteristik & $\mathbf{N}$ & $(\%)$ \\
\hline $\begin{array}{c}\text { Jenin Kelamin } \\
\text { Laki-laki } \\
\text { Perempuan }\end{array}$ & $\begin{array}{l}11 \\
15\end{array}$ & $\begin{array}{l}42,3 \\
57,7\end{array}$ \\
\hline Total & 26 & $100 \%$ \\
\hline $\begin{array}{ll}\text { Usia } & \\
& 40-50 \\
& 51-60 \\
& >60\end{array}$ & $\begin{array}{c}6 \\
8 \\
12\end{array}$ & $\begin{array}{l}23,1 \\
30,8 \\
46,1\end{array}$ \\
\hline Total & 26 & $100 \%$ \\
\hline
\end{tabular}

Tabel 2. Distribusi Hasil Pre-test dan Post-test berdasarkan interpretasi total skor WOMAC Kelompok I dan Kelompok II

\begin{tabular}{ccccccccc}
\cline { 2 - 7 } $\begin{array}{c}\text { Kelompok I Hold } \\
\text { Relax \& OKC }\end{array}$ & \multicolumn{2}{c}{ Ringan } & \multicolumn{2}{c}{ Sedang } & \multicolumn{2}{c}{ Berat } & \multicolumn{2}{c}{ Sangat Berat } \\
\cline { 2 - 9 } & $\mathrm{n}$ & $(\%)$ & $\mathrm{n}$ & $(\%)$ & $\mathrm{n}$ & $(\%)$ & $\mathrm{n}$ & $(\%)$ \\
\hline Pre-Test & 0 & 0 & 1 & 7,7 & 12 & 92,3 & 0 & 0 \\
Post-Test & 0 & 0 & 7 & 53,8 & 6 & 46,2 & 0 & 0 \\
\hline
\end{tabular}

\section{Interpretasi Total Skor WOMAC}

\begin{tabular}{ccccccccc}
\hline \multirow{2}{*}{$\begin{array}{c}\text { Kelompok II Hold } \\
\text { Relax \& CKC }\end{array}$} & \multicolumn{2}{c}{ Ringan } & \multicolumn{2}{c}{ Sedang } & \multicolumn{2}{c}{ Berat } & \multicolumn{2}{c}{ Sangat Berat } \\
\cline { 2 - 10 } & $\mathrm{n}$ & $(\%)$ & $\mathrm{n}$ & $(\%)$ & $\mathrm{n}$ & $(\%)$ & $\mathrm{n}$ & $(\%)$ \\
\hline Pre-Test & 0 & 0 & 1 & 7,7 & 12 & 92,3 & 0 & 0 \\
Post-Test & 3 & 23,1 & 9 & 69,2 & 1 & 7,7 & 0 & 0 \\
\hline
\end{tabular}


Tabel 3. Uji Normalitas

\begin{tabular}{|c|c|c|c|c|}
\hline Hasil WOMAC & Mean & $\begin{array}{c}\text { Std. } \\
\text { Deviation }\end{array}$ & $\begin{array}{c}\text { Shapiro-wilk } \\
\text { (P) }\end{array}$ & Keterangan \\
\hline Pre Test Kel. I & 59,62 & 9,483 & 0,517 & Distribusi Normal \\
\hline Post Test Kel. I & 49,31 & 10,617 & 0,450 & Distribusi Normal \\
\hline Pre Test Kel. II & 59,31 & 9,978 & 0,296 & Distribusi Normal \\
\hline Post Test Kel. II & 35,15 & 8,184 & 0,173 & Distribusi Normal \\
\hline Selisih Hasil Pre Post Kel. I & 10,31 & 1,601 & 0,788 & Distribusi Normal \\
\hline $\begin{array}{c}\text { Selisih Hasil Pre Post Kel. } \\
\text { II }\end{array}$ & 24,15 & 8,659 & 0,128 & Distribusi Normal \\
\hline
\end{tabular}

Tabel 4. Uji Paired Sample T

\begin{tabular}{|c|c|c|c|}
\hline $\begin{array}{l}\text { Hasil WOMAC } \\
\text { Kelompok I }\end{array}$ & Mean & Std. Deviation & $\begin{array}{c}\text { Uji Paired Sample T } \\
\text { (P) }\end{array}$ \\
\hline $\begin{array}{l}\text { Pre Test } \\
\text { Post Test }\end{array}$ & $\begin{array}{l}59,62 \\
49,31\end{array}$ & $\begin{array}{c}9,489 \\
10,617\end{array}$ & 0,014 \\
\hline $\begin{array}{c}\text { Hasil WOMAC } \\
\text { Kelompok II }\end{array}$ & Mean & Std. Deviation & $\begin{array}{c}\text { Uji Paired Sample T } \\
\end{array}$ \\
\hline $\begin{array}{l}\text { Pre Test } \\
\text { Post Test }\end{array}$ & $\begin{array}{l}59,31 \\
35,15\end{array}$ & $\begin{array}{l}9,978 \\
8,184\end{array}$ & 0,000 \\
\hline
\end{tabular}

Tabel 5. Uji Independent Sample T

\begin{tabular}{ccccc}
\hline Hasil WOMAC & Mean & Std. Deviation & $\begin{array}{c}\text { Independent } \\
\text { Sample T }\end{array}$ & Keterangan \\
\cline { 3 - 4 } & & & Sig.(P) & \\
\hline Hasil Selisih Pre Post Kel. I & 10,31 & 1,601 & 0,000 & Ada Perbedaan Pengaruh \\
Hasil Selisih Pre Post Kel. II & 24,15 & 8,659 & & \\
\hline
\end{tabular}

\section{KESIMPULAN}

Terdapat perbedaan pengaruh antara Kombinasi Latihan Hold Relax dan Open Kinetic Chain dengan Kombinasi Latihan Hold Relax dan Close Kinetic Chain terhadap peningkatan kemampuan fungsional pasien osteoartritis knee. Disarankan kepada penderita untuk memperhatikan hal-hal yang mempengaruhi kualitas pemulihan seperti aktivitas fisik, psikis dan motivasi untuk menunjang tercapainya hasil yang optimal. Kepada rekan-rekan mahasiswa dan praktisi fisioterapis dapat mengembangkan penelitian lebih lanjut dengan jumlah sampel yang lebih banyak dan jangka waktu yang lebih panjang sehingga hasilnya lebih efektif dan lebih maksimal.

\section{DAFTAR PUSTAKA}

1. Litwic. 2013. Epidemiology and Burden of Osteoarthritis. Europe PMC Funders Group. No. 105, Vol. 10, Hal. 185-199

2. Susilawati, I., Tirtayasa, K. \& Lesmana, S. I. 2015. Latihan Close Cinetic Chain Lebih Baik dari pada Open Kinetic Chain untuk Meningkatkan Kemampuan Fungsional pada Osteoarthritis Lutut setelah Pemberian Microwave Diathermy (MWD) dan Nerve Stimulation (TENS). Sport and Fitness Journal Volume 3, No 1: 26-34.

3. Masyhurrosyidi H, Kumboyono dan Utami YW. 2013. Pengaruh Kompres Hangat Rebusan Jahe terhadap tingkat nyeri subkutan dan kronis pada lanjut usia dengan osteoarthritis lutut di 
Puskesmas Arjuna Kecamatan Klojen Malang Jawa Timur. Program keperawatan: Fakultas Kedokteran Universitas Brawijaya, Malang.

4. Lestari, Desfi, 2014. Osteoartritis Genu Bilateral On 53 Years Old Woman With Grade II Hypertension. Vol 3 No 1.

5. Ebnezar, J., Nagarathna, R., Bali, Y. \& Nagendra, H.R. 2011. Effect of an integrated approach of yoga therapy on quality of life in osteoarthritis of the knee joint: A randomized control study. International Journal of Yoga; 4:55-63

6. Ismaningsih, Iit Selviani. 2018. Penatalaksanaan Fisioterapi Pada Kasus Osteoarthritis Genue Bilateral Dengan Intervensi Neuromuskuler Taping Dan Strengthening Exercise Untuk Meningkatkan Kapasitas Fungsional. Jurnal Ilmiah Fisioterapi (JIF) Volume 1 nomor 02 .

7. Connell. 2015. Exercise for osteoarthritis of the knee. avaiable from http://www.cochrane.org/ CD004376/ Muskel-exercise-for-osteoarthritis-ofthe-knee, doi:10. 1002/14651858.

8. Shaneen, A. 2008 . Imfact cronic osteoarthritis of knee joint on postural stability and mobility in women. Vol 13. No 1.

9. Lateef, Ramon. 2018. Effects of a 12week neuromuscular electrical stimulation and kinetic chain exercises on knee osteoarthritis in Nigeria. Thesis. Federal Medical Centre Abeokuta.

10. Adler, Susan and Dominiek, Beckers. 2014. PNF in Practice 4th. Berlin : Springer.

11. Verma S. 2012. Comparing open kinetic chain with closed kinetic chain exercise on quadriceps strength and functional status of women with osteoarthritic knees. Medicina Sportiva, Vol VIII, No 4, pp. 1989-1996.

12. Gbiri CA., Okafor UAC., Alade MT. 2013. Comparative Efficacy of Openchain and Close-chain Kinematics on Proprioception, Muscles' Strength and Functional Performances in Individual with Knee Osteoarthritis. Occup Med Health Aff 1: 104. doi:10.4172/23296879.1000104

13. Olagbegi OM., Adegoke BOA \& Odole A. 2016. Effectiveness of combined chain exercises on pain and function in patients with knee osteoarthritis. Bangladesh Journal of Medical Science Vol. 15 No. 02.

14. Maini, F. 2013. Intervensi Sonophorosis Diclofenac dan Hold Relax Lebih Baik dari pada Intervensi Ultrasound dan Hold Relax dalam Meningkatkan Kemampuan Fungsional pada Kasus Osteoartritis Tibiofemoral Joint. Jakarta: Fakultas Fisioterapi Universitas Esa Unggul.

15. Nurdin, M., Gani, M., \& Ramba, Y., 2013. Efektivitas antara Pemberian MWD dan Hold Relax dengan MWD dan Traksi Translasi terhadap Penurunan Nyeri dan Penambahan Luas Gerak Sendi Lutut Penderita Osteoarthritis Di Rumah Sakit Umum Haji Makassar. [online] (1.5) Available at: HYERLINK http://www.poltekkes-mks.ac.id http://www.poltekkes-mks.ac.id [Accessed 20 Juli 2014].

16. Paerunan, Cornelia., Gessal Joudy., Sengkey Lidwina.2019. Hubungan Antara Usia Dan Derajat Kerusakan Sendi Pada Pasien Osteoartritis Lutut Di Instalasi Rehabilitasi Medik Rsup. Prof. Dr. R. D. Kandou Manado Periode Januari - Juni 2018. Ilmu Kedokteran Fisik dan Rehabilitasi RSUP. Prof. Dr. R. D. Kandou Manado Jurnal Medik dan Rehabilitasi (JMR), Volume 1,Nomor 3

17. Widhiyanto. L, Desnantyo. A.T, Djuari. L, \& Kharismansha. M. 2017. Correlation Between Knee Osteoarthritis (OA) Grade and Body Mass Index (BMI) in Outpatients of Orthopedic and Traumatology Department RSUD Dr. Soetomo. Journal Orthopedi and Traumatology Surabaya. 6(2). 24-32.

18. Mutiwara, E. Najirman \& Afriwardi. 2016. Hubungan Indeks Massa Tubuh dengan Derajat Kerusakan Sendi pada Pasien Osteoarthritis Lutut di RSUP Dr. M. Djamil Padang. Jurnal Kesehatan Andalas. 5(2). 376-380.

19. Miftakuljannah dan Hartutik, Sri.2018. Tingkat Obesitas dengan Nyeri Persendian Lutut Pada Lansia. Jurnal Gaster. XVI(2). 206-215.

20. Misnadiarly. 2010. Osteoarthritis: Penyakit Sendi pada Orang Dewasa dan Anak. Jakarta: Pustaka Populer

21. Khairi, Nikmatul. 2018. Perbedaan Pengaruh Kombinasi Sling Exercise 
Pada Latihan Closed Kinetic Chain Dan

Open Kinetic Chain Terhadap Peningkatkan Kemampuan Fungsional Pada Osteoarthritis. Skripsi. Yogyakarta. Fakultas Ilmu Kesehatan Universitas 'Aisyiyah.

22. Fitzgerald, K. 2015. Open Versus Closed Kinetic Chain Exercise: Issues in Rehabilitation After Anterior Cruciate Ligament Reconstructive Surgery. Journal of the America Physical Therapy Association. November 2.

23. Gbiri CA., Okafor UAC., Alade MT. 2013. Comparative Efficacy of Openchain and Close-chain Kinematics on Proprioception, Muscles' Strength and Functional Performances in Individual with Knee Osteoarthritis. Occup Med
Health Aff 1: 104. doi:10.4172/23296879.1000104

24. Kisner, C dan Colby, L.A. 2012. Therapeutic Exercise Foundations and Techiques, (Vol. 6th Edition). Philadelphia: F.A.Davis Company

25. Kinandana, G.P., Nurmawan, I.P.S., dan Adiputra, I.N. 2016. Intervensi Ultrasound Dan Perturbation Training Lebih Efektif Dibandingkan Dengan Ultrasound Dan Closed Kinematic Chain Exercise Terhadap Peningkatan Kemampuan Fungsional Pada Penderita Osteoarthritis Genu Grade 2.

26. Mansfield P dan Neumann D. 2009. Essentials Of Kinesiology For The Physical Therapist Assistant. Philadelphia: Mosby Affiliateof Elsevier Science. 